\title{
Structure and Biophysics of Type III Secretion in Bacteria
}

\author{
Srirupa Chatterjee, Sukanya Chaudhury, Andrew C. McShan, Kawaljit Kaur, and Roberto N. \\ De Guzman* \\ Department of Molecular Biosciences, University of Kansas, Lawrence, Kansas 66045, United \\ States
}

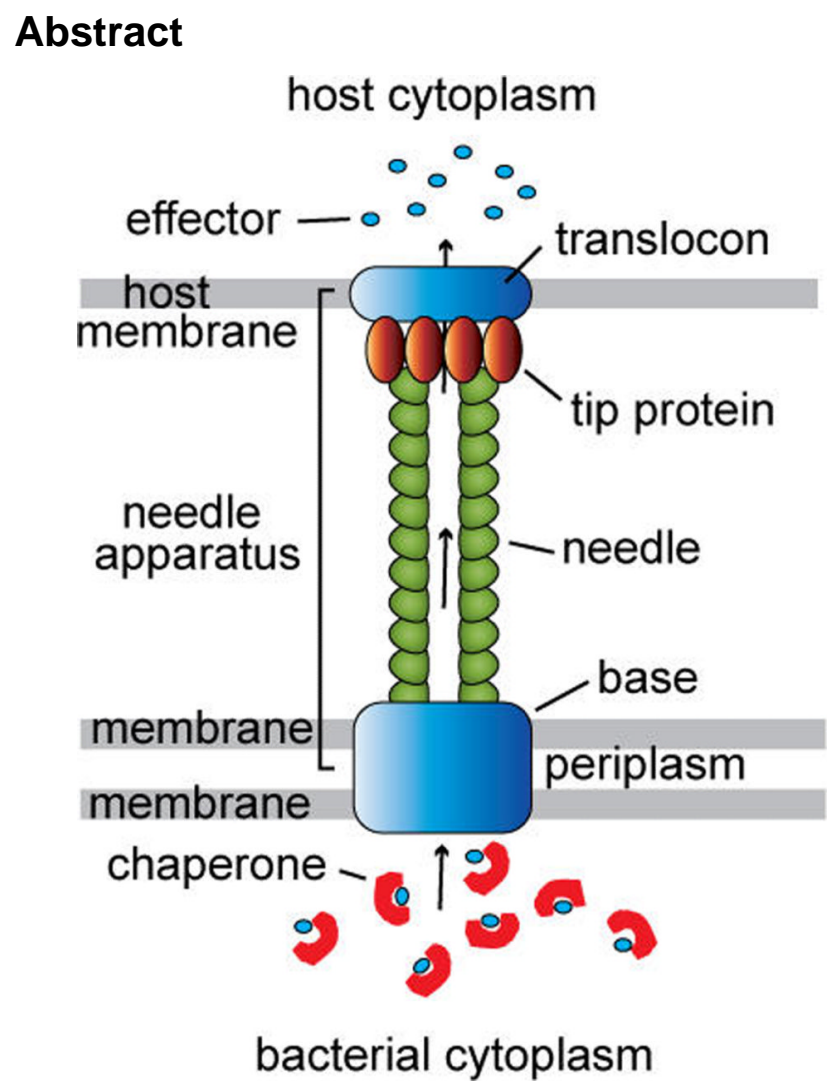

Many plant and animal bacterial pathogens assemble a needle-like nanomachine, the type III secretion system (T3SS), to inject virulence proteins directly into eukaryotic cells to initiate infection. The ability of bacteria to inject effectors into host cells is essential for infection, survival, and pathogenesis for many Gram-negative bacteria, including Salmonella, Escherichia, Shigella, Yersinia, Pseudomonas, and Chlamydia spp. These pathogens are responsible for a wide variety of diseases, such as typhoid fever, large-scale food-borne illnesses, dysentery, bubonic plague, secondary hospital infections, and sexually transmitted diseases. The T3SS consists of structural and nonstructural proteins. The structural proteins assemble the needle apparatus, which consists of a membrane-embedded basal structure, an external needle that protrudes from the

(C) 2013 American Chemical Society

*Corresponding Author Telephone: (785) 864-4923. Fax: (785) 864-9822. rdguzman@ ku.edu..

Author Contributions S. Chatterjee and S. Chaudhury contributed equally to this work.

The authors declare no competing financial interest. 
bacterial surface, and a tip complex that caps the needle. Upon host cell contact, a translocon is assembled between the needle tip complex and the host cell, serving as a gateway for translocation of effector proteins by creating a pore in the host cell membrane. Following delivery into the host cytoplasm, effectors initiate and maintain infection by manipulating host cell biology, such as cell signaling, secretory trafficking, cytoskeletal dynamics, and the inflammatory response. Finally, chaperones serve as regulators of secretion by sequestering effectors and some structural proteins within the bacterial cytoplasm. This review will focus on the latest developments and future challenges concerning the structure and biophysics of the needle apparatus.

\section{OVERVIEW OF THE NEEDLE APPARATUS}

More than a dozen different structural proteins assemble to form the type III secretion system (T3SS) needle apparatus. The needle complex, which consists of a basal structure and an external needle, was first visualized by electron microscopy of osmotically shocked Salmonella typhimurium. ${ }^{1}$ Similar structures were also observed in other bacteria, such as Shigella flexneri, ${ }^{2}$ Yersinia pestis, ${ }^{3}$ Escherichia coli, ${ }^{4}$ and Pseudomonas aeruginosa. ${ }^{5}$ Following years of extensive genetic, biochemical, and biophysical research, the core components of the complex were identified. The $~ 3.5 \mathrm{MDa}$ needle complex contains a basal structure spanning the periplasm that is embedded within the inner and outer bacterial membranes followed by a needle-like structure that protrudes into the extracellular space (Figure 1). In Salmonella, the basal structure is assembled from oligomeric rings of InvG, $\operatorname{PrgK}$, and $\operatorname{PrgH},{ }^{6}$ and an inner rod structure formed by PrgJ. ${ }^{7}$ The basal structure supports the entire needle complex by anchoring the needle on the bacterial membranes. The needle itself is composed of protomers of PrgI arranged in a spiral symmetry around a central $~ 25$ $\AA$ diameter channel to allow the passage of effector proteins. ${ }^{8}$ At the needle tip, multiple copies of SipD form a platform for the translocon. ${ }^{9}$ Upon contact with the host cell, the assembly of the entire needle apparatus is completed by the formation of the translocon, which is formed by the transmembrane proteins SipB and SipC. ${ }^{9}$ Structural homologues of each protein are present in the T3SSs of other Gram-negative bacteria (Table 1). The assembly of the needle apparatus is a highly regulated process involving specific proteinprotein, protein-membrane, and protein-small molecule interactions. Likewise, the order of protein secretion is also regulated; ${ }^{10}$ for example, needle proteins pass through the nascent apparatus prior to the tip and the translocon proteins. Each protein plays a critical role in the proper assembly of the needle apparatus, as null mutations of any of the structural components render bacteria incapable of assembling a functional needle apparatus. ${ }^{11}$ The following sections will focus on the structure, biophysics, and protein-protein interactions of the core components of the T3SS needle apparatus.

\section{BASAL STRUCTURE}

The basal structure anchors the needle to the bacterial membranes by traversing the inner membrane (IM), the periplasm, and the outer membrane $(\mathrm{OM}) .{ }^{1}$ The base measures approximately $250 \AA \times 300 \AA$ and is comparable in size to the flagellar basal body. ${ }^{6} \mathrm{PrgH}$, PrgK, and InvG assemble into ringlike structures at the IM and OM in Salmonella. ${ }^{6}$ The IM and $\mathrm{OM}$ rings enclose a tubelike inner rod structure formed by $\operatorname{PrgJ}^{7}$ in Salmonella, MxiI ${ }^{12}$ in Shigella, and YscI ${ }^{13}$ in Yersinia. The atomic structure of the assembled inner rod is currently unknown; however, NMR and circular dichroism spectroscopy indicate that PrgJ in the monomeric form is a partially folded protein. ${ }^{14}$ Further, yeast two-hybrid and GST pull-down experiments showed a direct binding interaction between the Yersinia inner rod protein YscI and the needle protomer YscF. ${ }^{15}$

In Salmonella, the IM ring structure is formed by $\operatorname{PrgH}$ and PrgK, which assemble into two concentric rings, with $\operatorname{PrgK}$ forming the smaller ring and $\operatorname{PrgH}$ forming the outer ring6,12,16 
(Figure 2A,B). PrgK belongs to the highly conserved YscJ/EscJ family of periplasmic lipoproteins, and NMR results for the enteropathogenic E. coli (EPEC) EscJ revealed a twodomain structure connected by a flexible linker (Figure 2C). ${ }^{17}$ These proteins are localized to the outer leaflet of the IM with their lipidated $\mathrm{N}$-terminal domain and contain $\mathrm{N}$-terminal signal sequences that are cleaved upon insertion in the membrane. ${ }^{12,17,18} \mathrm{X}$-ray crystallography showed that EscJ packs into a 24-mer ring structure ${ }^{18}$ with overall dimensions similar to those of the IM rings. ${ }^{19}$ Homology modeling based on the EscJ template generated the atomic model of Salmonella PrgK, which was then fit into the EM density map of the Salmonella base. ${ }^{20}$ The outer IM ring consists of 24 monomers of PrgH, a bitopic membrane protein with an $\mathrm{N}$-terminal cytoplasmic domain and a large $\mathrm{C}$-terminal periplasmic domain. ${ }^{20,21}$ The crystal structure of PrgH (residues 170-362) showed a distinctive "boot-shaped" organization of its modular domains (Figure 2C). ${ }^{21}$ The NMR structure of the N-terminal domain of Shigella MxiG (Figure 2C) (the homologue of Salmonella PrgH) supported the 24-subunit structure of the Shigella IM ring. ${ }^{22}$

The OM ring is formed by the secretin family of integral membrane proteins that includes Salmonella InvG,${ }^{20}$ Yersinia YscC, ${ }^{23}$ Shigella MxiD, ${ }^{24}$ and EPEC EscC. ${ }^{21}$ A neck region spanning the periplasm connects the OM ring to the IM rings. The N-terminal domain of InvG forms the neck region of the base and is associated with the PrgH IM ring, ${ }^{20}$ whereas the C-terminal domain forms the rest of the OM ring. ${ }^{21}$ Electron microscopy of the Shigella base at 21-25 A resolution showed an OM ring with a 12-fold symmetry. ${ }^{24}$ Recently, the refined structure of the Salmonella base at $10 \AA$ resolution showed a 15 -fold symmetry for the OM ring (Figure 2B). ${ }^{20}$ This higher-resolution structure of the base was achieved by selectively disassembling the basal components into stable IM and OM rings by $\mathrm{pH}$ treatment. ${ }^{20}$ The structural model of the Salmonella InvG based on the crystal structure of EPEC EscC (Figure 2C) was fit into the EM density map of the Salmonella basal structure to generate an atomic model of the Salmonella OM ring. ${ }^{21}$

Secretins are transported to the OM with the help of pilotins, which are small lipoproteins that assist in the assembly of the OM ring. ${ }^{25}$ The Shigella pilotin protein MxiM forms a pseudo- $\beta$-barrel with a hydrophobic pocket for binding lipids. ${ }^{26}$ MxiM interacts with the secretin protein MxiD, and the binding interaction blocks the lipid-binding pocket in MxiM. ${ }^{25}$ The pilotins also contain a characteristic signal peptide leader sequence with a conserved cysteine residue can be lipidated. ${ }^{25}$ These features are thought to help in the membrane targeting of the secretin-pilotin complex. ${ }^{25}$

Secretion through the base is controlled by an export apparatus, ${ }^{27}$ which serves as a platform for the assembly of the basal structure and controls substrate specificity. ${ }^{27-29}$ The export apparatus is a complex of highly conserved integral membrane proteins: YscR, YscS, YscT, YscU, and YscV in Yersinia ${ }^{28,29}$ and SpaP, SpaQ, SpaR, SpaS, and InvA in Salmonella. ${ }^{27}$ In Yersinia, the assembly of the base and export apparatus is initiated independently at the outer and inner membranes. ${ }^{28,29}$ In Yersinia, the OM ring of the base is formed by the secretin protein YscC (and assisted by the YscW pilotin), which then recruits the outer IM ring protein, YscD. ${ }^{28}$ Simultaneously, the export apparatus proteins YscR, YscS, and YscT assemble at the inner membrane, which promote the polymerization of $\mathrm{YscV} .{ }^{29}$ These two pathways can independently recruit the inner IM ring protein, YscJ, which is thus thought to link these two substructures. ${ }^{29}$ However, in Salmonella, the prior assembly of the export apparatus proteins ( $\mathrm{SpaP}, \mathrm{SpaQ}$, and $\mathrm{SpaR}$ ) at the IM is required for the assembly of the IM ring. ${ }^{27}$

The hierarchy of secretion of structural components and virulence effectors through the base is regulated in part by the export apparatus protein $\mathrm{YscU}$ in Yersinia, ${ }^{30} \mathrm{SpaS}$ in Salmonella, ${ }^{31}$ Spa40 in Shigella, ${ }^{32}$ and EscU in EPEC. ${ }^{31}$ The overall structure of these 
proteins consists of an $\mathrm{N}$-terminal transmembrane domain that is connected to a $\mathrm{C}$-terminal globular cytoplasmic domain by a flexible linker. ${ }^{30,31}$ The cytoplasmic domain shows a conserved fold composed of a central five-stranded mixed $\beta$-sheet surrounded by four $a$ helices. ${ }^{30-32}$ The cytoplasmic domain undergoes an autocatalytic cleavage at a highly conserved NPTH motif, resulting in an altered surface feature, which is important for substrate specificity switching. ${ }^{32}$ The largest component of the export apparatus, the $\mathrm{YscV}^{29}$ family of proteins (including Salmonella InvA ${ }^{33}$ and Shigella MxiA $^{34}$ ), forms a ring directly below the base. The atomic structures of the cytosolic domains of InvA, ${ }^{33} \mathrm{MxiA},{ }^{34}$ and the flagellar homologue $\mathrm{FlhA}^{35}$ show a conserved fold composed of four subdomains. The cytosolic domain of Shigella MxiA formed a nonameric ring, and residues lining the internal surface of this ring are important for secretion of T3SS substrates. ${ }^{34}$

An ATPase complex associated with the bacterial $\mathrm{IM}^{36}$ is responsible for energizing the export of substrates through the needle apparatus. The ATPase complex couples ATP hydrolysis to the unfolding and release of effector proteins from their cognate chaperones prior to secretion through the needle apparatus. ${ }^{34,37}$ The major component of the ATPase complex is a homohexamer formed by the $\mathrm{EscN}$ protein family (with homologues listed in Table 1), which is related to the $a$ and $\beta$ subunits of the F1 ATP synthase. ${ }^{38}$

\section{STRUCTURE OF THE NEEDLE}

The needle is assembled from multiple copies of a single protein, the needle protomer. Needle protomers are small polar proteins of $<90$ residues. ${ }^{12}$ Early experiments with recombinant forms of these proteins impeded structure determination because of their tendency to aggregate in solution. ${ }^{39}$ However, deletion of the last five residues at the Cterminus allowed for determination of the atomic structure of the Shigella needle protomer MxiH by crystallography, ${ }^{40}$ and Burkholderia $\mathrm{BsaL}^{41}$ and Salmonella $\operatorname{PrgI}^{42}$ needle protomers by NMR spectroscopy (Figure 3A). Unfortunately, this deletion also inhibited polymerization of the needle and abolished host cell invasion. ${ }^{43}$ Shortly after, the crystal and NMR structures of a soluble and functional V65A/V67A double mutant of full-length PrgI were determined (Figure 3A). ${ }^{43}$ The monomeric forms of needle protomers adopt a-helical hairpin structures, essentially two a-helices joined by a four-residue PXXP motif (where X is any amino acid), containing a turn in the central region of the protein (Figure 3A). The Pseudomonas PscF, however, lacks a PXXP motif and instead contains an AXXP motif. ${ }^{44}$ Complete structures of the Yersinia YscF and Pseudomonas PscF needle protomers are currently unknown; however, their partial structures in complex with their chaperones (YscE-YscG ${ }^{45}$ and PscE-PscG, ${ }^{44}$ respectively) are known. The structured regions of $\mathrm{YscF}$ (Figure 3A) and PscF in these complexes also form a-helices. Although $\mathrm{YscF}$ and PscF have chaperones, no chaperones have been reported for BsaL, MxiH, or PrgI.

Multiple copies of needle protomers assemble to form the T3SS needle. Electron microscopy and X-ray fiber diffraction of Shigella needles allowed the atomic scale modeling of a T3SS needle at $16 \AA$ resolution. ${ }^{46}$ This model revealed a structure measuring $500 \AA$ in length and $70 \AA$ in width enclosing an inner channel with a diameter of $\sim 25 \AA .46$ Subsequently, when the atomic structures of needle protomers became available, they were used to fit the electron density maps of the Shigella ${ }^{40}$ and Salmonella ${ }^{8}$ needles. The Nterminal region of MxiH lacked electron density in the crystal structure. ${ }^{40}$ Therefore, it was modeled in the Shigella needle as an a-helix facing the lumen, based on the predicted ahelical propensities of residues within the region. ${ }^{40}$ Similarly, in the Salmonella needle model, approximately half of the length of PrgI containing the flexible $\mathrm{N}$ - and C-termini was absent because of the conformational heterogeneity of the PrgI protomer in the NMR structure. ${ }^{8}$ The Shigella needle was shown to contain $\sim 5.6$ subunits per turn with a helical 
pitch of $24 \AA,{ }^{40}$ while the Salmonella needle contained $\sim 6.3$ subunits per turn with a helical pitch of $26 \AA^{8}$

Recently, higher-resolution atomic models of the Shigella ${ }^{47}$ and Salmonella ${ }^{48}$ needles were reported. These models represent our current understanding of the atomic structures of the T3SS needles. Fujii et al. used cryo-electron microscopy (cryo-EM) to determine the structure of purified Shigella needles formed by the overexpression of recombinant fulllength MxiH. ${ }^{47}$ The atomic model of the Shigella needle was obtained by fitting the crystal structure of MxiH residues 26-51 (the "head" structure) into the $7.7 \AA$ resolution electron density map. ${ }^{47}$ In this model, the first 38 residues of $\mathrm{MxiH}$ form a straight a-helix facing the lumen and the exterior surface of the needle is formed by the $\mathrm{C}$-terminus of $\mathrm{MxiH}$, which contains a short a-helix (residues 44-50), a $\beta$-hairpin (residues 51-64), and a kinked helix (residues 65-83). ${ }^{47}$ Intersubunit interactions are present between the $\beta$-hairpin and the PXXP motif, as well as the $\beta$-hairpin and the $\mathrm{C}$-terminus of adjacent subunits. The needle is further stabilized by helix-helix interactions between adjacent subunits.

Loquet et al., ${ }^{48}$ on the other hand, used solid-state NMR spectroscopy (ssNMR) to determine the structure of Salmonella needles polymerized from full-length recombinant PrgI (Figure 3B). The use of $\left[1-{ }^{13} \mathrm{C}\right]$ glucose or $\left[2-{ }^{13} \mathrm{C}\right]$ glucose instead of the traditional uniform labeling with ${ }^{13} \mathrm{C}$-labeled glucose ${ }^{49}$ as the carbon source for bacteria expressing recombinant PrgI reduced the NMR signal complexity of the megadalton needle. Coupled with ${ }^{15} \mathrm{~N}$ labeling, ssNMR allowed the identification of intra- and intersubunit ${ }^{15} \mathrm{~N}-{ }^{13} \mathrm{C}$ distance restraints, ${ }^{48}$ which were used in combination with Rosetta modeling ${ }^{50}$ to generate the atomic structure of the Salmonella needle ${ }^{48}$ (Figure 3B). According to the ssNMR model, the Salmonella needle is composed of PrgI protomers with an a-helical hairpin head structure similar to those that have been described previously. ${ }^{42,43}$ However, unlike previously determined crystal and NMR structures, ssNMR secondary structure analysis excluded conformational heterogeneity at the $\mathrm{N}$ - and C-termini, except for Met1 and Ala2.48 The Salmonella needle has an $80 \AA$ outer diameter with a $25 \AA$ lumen, similar to values previously described. ${ }^{8,51}$ Unlike previous reconstructions, ${ }^{8}$ however, the needle was shown to contain $\sim 5.7$ subunits per turn with a helical pitch of $24 \AA .{ }^{48}$ The needle is held together by multiple intra- and intersubunit contacts. The intrasubunit contacts are primarily hydrophobic interactions between the two helices of the hairpin, and the intersubunit interactions are present on the lateral and axial surfaces of each subunit. ${ }^{48}$

There are two major differences between the ssNMR model ${ }^{48}$ of the Salmonella needle and previous needle models. ${ }^{8,40,47}$ The first difference is that in the ssNMR Salmonella needle model, the N-terminus of PrgI faces the exterior of the needle while the C-terminal tail faces the interior ${ }^{48}$ (Figure $3 \mathrm{~B}$ ). Immunoelectron microscopy against the $\mathrm{N}$-terminus of PrgI confirmed that nonconserved residues in the $\mathrm{N}$-terminal region face the exterior of the needle, while highly conserved residues in the C-terminus are contained within the lumen. ${ }^{48}$ In contrast, the EM models have reported that the $\mathrm{N}$-terminus of the needle protomer faces the lumen while the C-terminus faces the exterior. 8,40,47 This was supported by secretion experiments in which the N-terminus of MxiH tolerated more substantial modifications than the C-terminus. ${ }^{47}$ Another difference is that throughout the Salmonella needle protomer, no $\beta$-hairpin was detected, in contrast to the structure of the Shigella needle protomer. ${ }^{47}$ Poyraz et al., ${ }^{43}$ however, reported that residues I71-I76 of PrgI V65A/V67A undergo a backbone $a$-helix- $\beta$-strand conversion upon polymerization. In the Shigella needle, the $\beta$-hairpin is hypothesized to regulate assembly and the positioning of the subunits within the needle. ${ }^{47}$ ssNMR data of Shigella needles should clarify these differences. 


\section{NEEDLE TIP}

On the distal end of the needle sits a tip protein complex that functions to sense the presence of eukaryotic cells, to serve as a platform for the assembly of the translocon, and to regulate the secretion of effector proteins into the host cell. ${ }^{9,52}$ The T3SS tip proteins can be grouped into two classes based on their structures and properties. One class is formed by Salmonella SipD, Shigella IpaD, and Burkholderia BipD tip proteins, which have sequences that are 30$50 \%$ identical and are structural homologues with a Ca root-mean-square deviation of $<1.5$ $\AA .53-56$ Members of the SipD family of tip proteins share a more distant resemblance to another class of tip proteins, the Yersinia LcrV and the Pseudomonas PcrV tip proteins, with sequences that are $\sim 37 \%$ identical.

The SipD, IpaD, and $\mathrm{BipD}^{53-56}$ tip proteins contain eight $\alpha$-helices and five $\beta$-strands, which are arranged into three distinct structural elements: an $\mathrm{N}$-terminal $\alpha$-helical hairpin, a long central coiled-coil, and a $\mathrm{C}$-terminal region of mixed $\alpha$-helices and $\beta$-strands (Figure $4 \mathrm{~A}-\mathrm{D})$. The central coiled-coil is a distinct structural feature of all tip proteins and is responsible for their overall oblong shape. The coiled-coil motif, especially the C-terminal residues, is important for the interaction of the tip protein with the needle, and the needle protomer is expected to bind at multiple sites on the coiled-coil motif. ${ }^{52,55-58} \mathrm{~A}$ threestranded antiparallel $\beta$-sheet connects the central coiled-coil to the mixed $\alpha / \beta$ region. ${ }^{53-55}$ The first 30-40 residues of the tip proteins are disordered in the crystal structures of SipD, $\mathrm{IpaD}$, and BipD. ${ }^{52}$ The $\mathrm{N}$-terminal a-hairpin folds independently and functions as a selfchaperone by preventing the self-oligomerization of SipD and $\mathrm{IpaD}^{53,56,59}$ and hinders the interaction between the needle protomer PrgI and the tip protein SipD. ${ }^{56}$ Upon assembly of $\mathrm{SipD}$ at the needle tip, the a-hairpin is expected to be displaced by the needle protomer, which interacts with the coiled-coil domain. ${ }^{53,56,58}$

The $2.2 \AA$ crystal structure of $\mathrm{LcrV}^{60}$ (Figure 4) represents what is currently known about the atomic structure of the Yersinia/Pseudomonas LcrV/PcrV family of tip proteins. Similar to the SipD, the structure of LcrV also contains a long central coiled-coil, which is flanked by globular domains on the $\mathrm{N}$ - and $\mathrm{C}$-termini, giving an overall "dumbbell shape" to LcrV. ${ }^{60} \mathrm{LcrV}$, however, lacks the self-chaperoning a-helical hairpin found in SipD. Instead, a small cytoplasmic protein, LcrG, functions as the chaperone for LcrV. ${ }^{11}$ Likewise, the LcrG homologue in Pseudomonas, PcrG, functions as a chaperone for the PcrV tip protein. In addition to binding their cognate tip proteins, $\mathrm{LcrG}$ and PcrG negatively regulate secretion of effectors ${ }^{61,62}$ in Yersinia and Pseudomonas. Deletion of $1 c r G$ decreases the level of LcrV secretion, ${ }^{63}$ and host cell contact with Yersinia upregulates the expression of LcrV, which then forms a tight binding complex with LcrG; this interaction relieves the negative block on effector secretion by titrating away LcrG. ${ }^{61,62,64}$ The N-terminal regions of LcrG and PcrG are required for binding to their cognate tip proteins, ${ }^{61,65,66}$ and the coiled-coil region of $\mathrm{LcrV}$ is involved in the interaction with LcrG. ${ }^{65,67}$ The absence of an intramolecular chaperoning domain in LcrV and PcrV hints at divergent assembly processes at the needle tip between the SalmonellalShigella and YersinialPseudomonas species.

A major challenge in this field is the determination of atomic-resolution structures of the tip protein docked at the needle tip. Currently, low-resolution electron micrographs of the Yersinia LcrV tip ${ }^{68}$ and the Shigella IpaD tip ${ }^{69,70}$ as well as models made by docking the crystal structures of tip proteins on the needle ${ }^{11,40}$ are available. Electron micrographs of the Yersinia needle tip show a well-defined tip complex that was estimated to be formed by an LcrV pentameric ring. ${ }^{68,71}$ The Yersinia LcrV tip complex showed a distinct head, neck, and a base, and Broz et al. ${ }^{71}$ concluded that the LcrV N-terminal globular domain forms the base, the C-terminal globular domain forms the head, and the coiled-coil region forms the 
neck. The base was also shown to be responsible for the correct insertion of the Yersinia translocon protein YopB into the host cell membrane. ${ }^{71}$

Results from electron microscopy of the Shigella tip complex also estimated a stoichiometry of a pentameric IpaD at the needle tip. ${ }^{70}$ However, the Shigella tip complex did not show the head, neck, and base morphology that was seen in the Yersinia needle tip. This difference was partly ascribed to the difference in the structure of IpaD and $\mathrm{LcrV}$ where the domains flanking the IpaD coiled-coil were more elongated in shape compared to the more globular domains flanking the LcrV coiled-coil. In the Shigella tip complex, the IpaD coiled-coil is aligned with the vertical axis of the tip complex with a $20^{\circ}$ tilt and the tip complex forms an internal channel diameter from $40 \AA$ at the middle to $22 \AA$ at the top. ${ }^{70}$ The most distinctive feature of this structure is that the IpaD mixed $\alpha / \beta$ domain undergoes a $165^{\circ}$ rotation about the horizontal axis, forming a scepterlike structure at the top of the tip complex ${ }^{70}$ In support of this drastic rotation, tip complexes made of IpaD lacking the mixed $\alpha / \beta$ domain (residues 192-267) were shorter by $\sim 37 \AA$ and lacked electron density for the scepterlike structure. ${ }^{70}$

Prior to contact with the host cell membrane, the tip complex is present at the needle tip while the translocon is yet to be assembled. ${ }^{9,69,72}$ The tip complex therefore controls the secretion of the translocon proteins, and this process is not well understood. It has been proposed that the pentameric tip complex forms a closed conformation that prevents protein secretion $^{11}$ and, upon receiving an extracellular signal in the presence of the host cell, ${ }^{72,73}$ changes into an open conformation that allows protein secretion to complete the assembly of the needle apparatus. Bile salts, levels of which are elevated in the intestines, have been identified as extracellular signals that can affect type III secretion in the enteric pathogens Shigella ${ }^{74-76}$ and Salmonella. ${ }^{77,78}$ Bile salts bind to $\mathrm{IpaD}^{72,73,75,76}$ and SipD; $56,76,79$ however, despite the structural homology of IpaD and SipD, bile salts bind these proteins at different sites and affect their respective T3SSs in opposite ways. Bile salts increase the level of type III secretion and invasiveness of Shigella ${ }^{74-76}$ but repress the transcription of T3SS proteins and decrease the invasiveness of Salmonella. ${ }^{77,78}$ The mechanism of how extracellular signals affect the structure and conformation of the tip complex remains to be elucidated.

\section{TRANSLOCON}

The final stage in the assembly of the needle apparatus is the formation of the translocon, which forms a 20-30 A pore on the host cell membrane to allow the passage of effectors into the host cell. ${ }^{2,80-82}$ The translocon is assembled from two integral membrane proteins named SipB and SipC in Salmonella, ${ }^{83} \mathrm{IpaB}$ and IpaC in Shigella, ${ }^{2,84}$ YopB and YopD in Yersinia, ${ }^{82}$ and PopB and PopD in Pseudomonas. ${ }^{85}$ The translocon proteins are important for the entry of bacteria into eukaryotic cells as demonstrated by the internalization of latex beads coated with IpaB and IpaC into HeLa cells. ${ }^{86}$ While inside the bacterial cytosol, the translocon proteins are bound to their chaperones to maintain their intracellular stability. SipB and SipC are chaperoned by SicA in Salmonella. ${ }^{87}$ The chaperones for the translocon proteins in other species are the Shigella IpgC, ${ }^{88}$ Yersinia SycD (also named LcrH), ${ }^{89}$ and Pseudomonas $\mathrm{PcrH}^{90}$ proteins.

The major translocon proteins from Shigella and Salmonella (IpaB and SipB) are $62 \mathrm{kDa}$ ahelical proteins that can bind to cell membranes. ${ }^{91}$ The Yersinia YopB and Pseudomonas PopB share a higher degree of conservation and are $\sim 40 \mathrm{kDa}$ in size. ${ }^{92}$ The N-terminal region of IpaB and SipB is responsible for their self-oligomerization. ${ }^{91}$ Two transmembrane helices facilitate intimate attachment to lipid membranes. ${ }^{91,93}$ The extreme C-terminus is predicted to form an amphipathic helix and is important for invasion of the host cell and regulation of effector secretion. ${ }^{91,94,95}$ The crystal structures of the protease resistant 
fragments in the N-terminal regions of IpaB (residues 74-224) and SipB (residues 82-226) revealed a trimeric coiled-coil domain formed by three antiparallel a-helices ${ }^{96}$ (Figure 5A).

The Shigella IpaC, ${ }^{52}$ Salmonella SipC,${ }^{9}$ Yersinia YopD,${ }^{97}$ and Pseudomonas PopD $^{98}$ are the minor translocon proteins and form complexes with the major translocon proteins, and this interaction is necessary for the attachment and entry into epithelial cells. ${ }^{9}$ Incubation of Shigella with recombinant IpaC led to an increased level of invasion of epithelial cells, ${ }^{99,100}$ and recombinant SipC can interact with actin. ${ }^{101}$ Similar to other T3SS proteins, the Nterminus of these molecules is required for their secretion, $9,100,102,103$ and a central hydrophobic region allows binding to lipid membranes. ${ }^{104}$ The C-terminus, which is predicted to be helical, has been implicated in actin modulation ${ }^{105-107}$ and hemolytic activity. ${ }^{108}$ In addition, the conserved C-terminus is also involved in the homotypic oligomerization of IpaC. ${ }^{100}$

The chaperones of the translocon proteins belong to class II of T3SS chaperones and are responsible for partitioning the intracellular pools of the major and minor translocon proteins, thereby preventing their premature degradation. ${ }^{87,109,110}$ Chaperones bind at the $\mathrm{N}$-terminal regions of translocon proteins..$^{90,111-114}$ Cocrystal structures of chaperones bound to peptides derived from the chaperone-binding regions of the translocon proteins revealed how chaperones recognize their cognate translocon proteins (Figure 5B). ${ }^{90,113,115}$ The chaperones form a homodimer of tetratricopeptide motifs composed of antiparallel ahelical repeats. In the cocrystal structure of the Shigella IpgC-IpaB peptide complex, ${ }^{115}$ $\mathrm{IpgC}$ forms a dimer with each IpgC molecule forming a concave cleft $\sim 10 \AA$ in width to accommodate the IpaB peptide, and the IpgC-IpaB protein-protein contacts are mediated by conserved residues on both proteins. The $32 \mathrm{~N}$-terminal residues of $\mathrm{IpgC}$ are responsible for its homodimerization, and this dimerization pattern is conserved in the Salmonella SicA ${ }^{115}$ and Yersinia SycD ${ }^{116}$ chaperones. Amino acid substitutions in the $\mathrm{IpgC} \mathrm{N}$-terminal region decreased the level of secretion of effectors and bacterial invasion. ${ }^{115}$

The major translocon proteins IpaB and SipB interact with lipids such as cholesterol and sphingomyelin, ${ }^{117,118}$ and cholesterol is required for effector translocation in Shigella, Salmonella, and EPEC. ${ }^{117,118}$ Further, the interaction of sphingomyelin and cholesterol with $\mathrm{IpaB}$ is proposed to induce the recruitment of IpaC to assemble the translocon. ${ }^{118} \mathrm{In}$ addition to their structural role in the assembly of the translocon, the translocon proteins are also delivered into the host cell where they interact with a number of cellular factors. ${ }^{119}$ IpaB binds to caspase-1, and this leads to apoptosis of macrophages. ${ }^{120,121}$ Furthermore, the C-terminus of IpaC induces actin polymerization and formation of filopodia and lamellipodia in fibroblast cells. ${ }^{105,106}$ Cytoskeletal rearrangements induced by IpaC were dependent on the function of Cdc42 and Rac GTPases. ${ }^{105,106}$ The C-terminus of SipC (within residues 200-409) could also induce actin polymerization in HeLa cells. ${ }^{105,106}$

\section{CONCLUSION}

Since the visualization of parts of the needle apparatus at low resolution 15 years ago, much progress has been achieved in determining atomic-resolution structures of components there-of from electron microscopy, crystallography, and NMR spectroscopy. However, much remains to be elucidated in understanding this macromolecular nanoinjector device. Among them are the atomic structures of the translocon and the tip complex. Because the needle apparatus plays a critical role in pathogenesis, understanding its assembly will contribute to the development of novel anti-infectives. 


\section{Acknowledgments}

Funding This work was supported by National Institutes of Health Grants T32-GM008359 (A.C.M.) and R01AI074856 (R.N.D.G.).

\section{ABBREVIATIONS}

$\begin{array}{ll}\text { T3SS } & \text { type III secretion system } \\ \text { OM } & \text { outer membrane } \\ \text { IM } & \text { inner membrane } \\ \text { EPEC } & \text { enteropathogenic E. coli } \\ \text { NMR } & \text { nuclear magnetic resonance } \\ \text { SSNMR } & \text { solid-state NMR } \\ \text { EM } & \text { electron microscopy }\end{array}$

\section{REFERENCES}

(1). Kubori T, Matsushima Y, Nakamura D, Uralil J, Lara-Tejero M, Sukhan A, Galan JE, Aizawa SI. Supramolecular structure of the Salmonella typhimurium type III protein secretion system. Science. 1998; 280:602-605. [PubMed: 9554854]

(2). Blocker A, Gounon P, Larquet E, Niebuhr K, Cabiaux V, Parsot C, Sansonetti P. The tripartite type III secreton of Shigella flexneri inserts IpaB and IpaC into host membranes. J. Cell Biol. 1999; 147:683-693. [PubMed: 10545510]

(3). Cornelis GR. Yersinia type III secretion: Send in the effectors. J. Cell Biol. 2002; 158:401-408. [PubMed: 12163464]

(4). Sekiya K, Ohishi M, Ogino T, Tamano K, Sasakawa C, Abe A. Supermolecular structure of the enteropathogenic Escherichia coli type III secretion system and its direct interaction with the EspA-sheath-like structure. Proc. Natl. Acad. Sci. U.S.A. 2001; 98:11638-11643. [PubMed: 11562461]

(5). Pastor A, Chabert J, Louwagie M, Garin J, Attree I. PscF is a major component of the Pseudomonas aeruginosa type III secretion needle. FEMS Microbiol. Lett. 2005; 253:95-101. [PubMed: 16239085]

(6). Marlovits TC, Kubori T, Sukhan A, Thomas DR, Galan JE, Unger VM. Structural insights into the assembly of the type III secretion needle complex. Science. 2004; 306:1040-1042. [PubMed: 15528446]

(7). Marlovits TC, Kubori T, Lara-Tejero M, Thomas D, Unger VM, Galan JE. Assembly of the inner rod determines needle length in the type III secretion injectisome. Nature. 2006; 441:637-640. [PubMed: 16738660]

(8). Galkin VE, Schmied WH, Schraidt O, Marlovits TC, Egelman EH. The structure of the Salmonella typhimurium type III secretion system needle shows divergence from the flagellar system. J. Mol. Biol. 2010; 396:1392-1397. [PubMed: 20060835]

(9). Lara-Tejero M, Galan JE. Salmonella enterica serovar typhimurium pathogenicity island 1encoded type III secretion system translocases mediate intimate attachment to nonphagocytic cells. Infect. Immun. 2009; 77:2635-2642. [PubMed: 19364837]

(10). Lara-Tejero M, Kato J, Wagner S, Liu X, Galan JE. A sorting platform determines the order of protein secretion in bacterial type III systems. Science. 2011; 331:1188-1191. [PubMed: 21292939]

(11). Blocker AJ, Deane JE, Veenendaal AK, Roversi P, Hodgkinson JL, Johnson S, Lea SM. What's the point of the type III secretion system needle? Proc. Natl. Acad. Sci. U.S.A. 2008; 105:65076513. [PubMed: 18458349] 
(12). Blocker A, Jouihri N, Larquet E, Gounon P, Ebel F, Parsot C, Sansonetti P, Allaoui A. Structure and composition of the Shigella flexneri "needle complex", a part of its type III secretion. Mol. Microbiol. 2001; 39:652-663. [PubMed: 11169106]

(13). Wood SE, Jin J, Lloyd SA. YscP and YscU switch the substrate specificity of the Yersinia type III secretion system by regulating export of the inner rod protein YscI. J. Bacteriol. 2008; 190:4252-4262. [PubMed: 18424518]

(14). Zhong D, Lefebre M, Kaur K, McDowell MA, Gdowski C, Jo S, Wang Y, Benedict SH, Lea SM, Galan JE, De Guzman RN. The Salmonella Type III Secretion System Inner Rod Protein PrgJ Is Partially Folded. J. Biol. Chem. 2012; 287:25303-25311. [PubMed: 22654099]

(15). Yang H, Tan Y, Zhang T, Tang L, Wang J, Ke Y, Guo Z, Yang X, Yang R, Du Z. Identification of Novel Protein-Protein Interactions of Yersinia pestis Type III Secretion System by Yeast Two Hybrid System. PLoS One. 2013; 8:e54121. [PubMed: 23349800]

(16). Schraidt O, Lefebre MD, Brunner MJ, Schmied WH, Schmidt A, Radics J, Mechtler K, Galan JE, Marlovits TC. Topology and organization of the Salmonella typhimurium type III secretion needle complex components. PLoS Pathog. 2010; 6:e1000824. [PubMed: 20368966]

(17). Crepin VF, Prasannan S, Shaw RK, Wilson RK, Creasey E, Abe CM, Knutton S, Frankel G, Matthews S. Structural and functional studies of the enteropathogenic Escherichia coli type III needle complex protein EscJ. Mol. Microbiol. 2005; 55:1658-1670. [PubMed: 15752191]

(18). Yip CK, Kimbrough TG, Felise HB, Vuckovic M, Thomas NA, Pfuetzner RA, Frey EA, Finlay BB, Miller SI, Strynadka NC. Structural characterization of the molecular platform for type III secretion system assembly. Nature. 2005; 435:702-707. [PubMed: 15931226]

(19). Moraes TF, Spreter T, Strynadka NC. Piecing together the type III injectisome of bacterial pathogens. Curr. Opin. Struct. Biol. 2008; 18:258-266. [PubMed: 18258424]

(20). Schraidt O, Marlovits TC. Three-dimensional model of Salmonella's needle complex at subnanometer resolution. Science. 2011; 331:1192-1195. [PubMed: 21385715]

(21). Spreter T, Yip CK, Sanowar S, Andre I, Kimbrough TG, Vuckovic M, Pfuetzner RA, Deng W, Yu AC, Finlay BB, Baker D, Miller SI, Strynadka NC. A conserved structural motif mediates formation of the periplasmic rings in the type III secretion system. Nat. Struct. Mol. Biol. 2009; 16:468-476. [PubMed: 19396170]

(22). McDowell MA, Johnson S, Deane JE, Cheung M, Roehrich AD, Blocker AJ, McDonnell JM, Lea SM. Structural and functional studies on the N-terminal domain of the Shigella type III secretion protein MxiG. J. Biol. Chem. 2011; 286:30606-30614. [PubMed: 21733840]

(23). Burghout P, van Boxtel R, Van Gelder P, Ringler P, Muller SA, Tommassen J, Koster M. Structure and electrophysiological properties of the $\mathrm{YscC}$ secretin from the type III secretion system of Yersinia enterocolitica. J. Bacteriol. 2004; 186:4645-4654. [PubMed: 15231798]

(24). Hodgkinson JL, Horsley A, Stabat D, Simon M, Johnson S, da Fonseca PC, Morris EP, Wall JS, Lea SM, Blocker AJ. Three-dimensional reconstruction of the Shigella T3SS transmembrane regions reveals 12-fold symmetry and novel features throughout. Nat. Struct. Mol. Biol. 2009; 16:477-485. [PubMed: 19396171]

(25). Okon M, Moraes TF, Lario PI, Creagh AL, Haynes CA, Strynadka NC, McIntosh LP. Structural characterization of the type-III pilot-secretin complex from Shigella flexneri. Structure. 2008; 16:1544-1554. [PubMed: 18940609]

(26). Lario PI, Pfuetzner RA, Frey EA, Creagh L, Haynes C, Maurelli AT, Strynadka NC. Structure and biochemical analysis of a secretin pilot protein. EMBO J. 2005; 24:1111-1121. [PubMed: 15775974]

(27). Wagner S, Konigsmaier L, Lara-Tejero M, Lefebre M, Marlovits TC, Galan JE. Organization and coordinated assembly of the type III secretion export apparatus. Proc. Natl. Acad. Sci. U.S.A. 2010; 107:17745-17750. [PubMed: 20876096]

(28). Diepold A, Amstutz M, Abel S, Sorg I, Jenal U, Cornelis GR. Deciphering the assembly of the Yersinia type III secretion injectisome. EMBO J. 2010; 29:1928-1940. [PubMed: 20453832]

(29). Diepold A, Wiesand U, Cornelis GR. The assembly of the export apparatus (YscR,S,T,U,V) of the Yersinia type III secretion apparatus occurs independently of other structural components and involves the formation of an YscV oligomer. Mol. Microbiol. 2011; 82:502-514. [PubMed: 21923772] 
(30). Wiesand U, Sorg I, Amstutz M, Wagner S, van den Heuvel J, Luhrs T, Cornelis GR, Heinz DW. Structure of the type III secretion recognition protein YscU from Yersinia enterocolitica. J. Mol. Biol. 2009; 385:854-866. [PubMed: 18976663]

(31). Zarivach R, Deng W, Vuckovic M, Felise HB, Nguyen HV, Miller SI, Finlay BB, Strynadka NC. Structural analysis of the essential self-cleaving type III secretion proteins EscU and SpaS. Nature. 2008; 453:124-127. [PubMed: 18451864]

(32). Deane JE, Graham SC, Mitchell EP, Flot D, Johnson S, Lea SM. Crystal structure of Spa40, the specificity switch for the Shigella flexneri type III secretion system. Mol. Microbiol. 2008; 69:267-276. [PubMed: 18485071]

(33). Worrall LJ, Vuckovic M, Strynadka NC. Crystal structure of the C-terminal domain of the Salmonella type III secretion system export apparatus protein InvA. Protein Sci. 2010; 19:10911096. [PubMed: 20306492]

(34). Abrusci P, Vergara-Irigaray M, Johnson S, Beeby MD, Hendrixson DR, Roversi P, Friede ME, Deane JE, Jensen GJ, Tang CM, Lea SM. Architecture of the major component of the type III secretion system export apparatus. Nat. Struct. Mol. Biol. 2013; 20:99-104. [PubMed: 23222644]

(35). Saijo-Hamano Y, Imada K, Minamino T, Kihara M, Shimada M, Kitao A, Namba K. Structure of the cytoplasmic domain of FlhA and implication for flagellar type III protein export. Mol. Microbiol. 2010; 76:260-268. [PubMed: 20199603]

(36). Pozidis C, Chalkiadaki A, Gomez-Serrano A, Stahlberg H, Brown I, Tampakaki AP, Lustig A, Sianidis G, Politou AS, Engel A, Panopoulos NJ, Mansfield J, Pugsley AP, Karamanou S, Economou A. Type III protein translocase: $\mathrm{HrcN}$ is a peripheral ATPase that is activated by oligomerization. J. Biol. Chem. 2003; 278:25816-25824. [PubMed: 12734178]

(37). Akeda Y, Galan JE. Chaperone release and unfolding of substrates in type III secretion. Nature. 2005; 437:911-915. [PubMed: 16208377]

(38). Zarivach R, Vuckovic M, Deng W, Finlay BB, Strynadka NC. Structural analysis of a prototypical ATPase from the type III secretion system. Nat. Struct. Mol. Biol. 2007; 14:131137. [PubMed: 17237797]

(39). Kenjale R, Wilson J, Zenk SF, Saurya S, Picking WL, Picking WD, Blocker A. The needle component of the type III secreton of Shigella regulates the activity of the secretion apparatus. J. Biol. Chem. 2005; 280:42929-42937. [PubMed: 16227202]

(40). Deane JE, Roversi P, Cordes FS, Johnson S, Kenjale R, Daniell S, Booy F, Picking WD, Picking WL, Blocker AJ, Lea SM. Molecular model of a type III secretion system needle: Implications for host-cell sensing. Proc. Natl. Acad. Sci. U.S.A. 2006; 103:12529-12533. [PubMed: 16888041]

(41). Zhang L, Wang Y, Picking WL, Picking WD, De Guzman RN. Solution structure of monomeric BsaL, the type III secretion needle protein of Burkholderia pseudomallei. J. Mol. Biol. 2006; 359:322-330. [PubMed: 16631790]

(42). Wang Y, Ouellette AN, Egan CE, Rathinavelan T, Im W, De Guzman RN. Differences in the electrostatic surfaces of the type III secretion needle proteins PrgI, BsaL, and MxiH. J. Mol. Biol. 2007; 371:1304-1314. [PubMed: 17617421]

(43). Poyraz O, Schmidt H, Seidel K, Delissen F, Ader C, Tenenboim H, Goosmann C, Laube B, Thunemann AF, Zychlinsky A, Baldus M, Lange A, Griesinger C, Kolbe M. Protein refolding is required for assembly of the type three secretion needle. Nat. Struct. Mol. Biol. 2010; 17:788792. [PubMed: 20543831]

(44). Quinaud M, Ple S, Job V, Contreras-Martel C, Simorre JP, Attree I, Dessen A. Structure of the heterotrimeric complex that regulates type III secretion needle formation. Proc. Natl. Acad. Sci. U.S.A. 2007; 104:7803-7808. [PubMed: 17470796]

(45). Sun P, Tropea JE, Austin BP, Cherry S, Waugh DS. Structural Characterization of the Yersinia pestis Type III Secretion System Needle Protein YscF in Complex with Its Heterodimeric Chaperone YscE/YscG. J. Mol. Biol. 2008; 377:819-830. [PubMed: 18281060]

(46). Cordes FS, Komoriya K, Larquet E, Yang S, Egelman EH, Blocker A, Lea SM. Helical structure of the needle of the type III secretion system of Shigella flexneri. J. Biol. Chem. 2003; 278:17103-17107. [PubMed: 12571230] 
(47). Fujii T, Cheung M, Blanco A, Kato T, Blocker AJ, Namba K. Structure of a type III secretion needle at 7-Å resolution provides insights into its assembly and signaling mechanisms. Proc. Natl. Acad. Sci. U.S.A. 2012; 109:4461-4466. [PubMed: 22388746]

(48). Loquet A, Sgourakis NG, Gupta R, Giller K, Riedel D, Goosmann C, Griesinger C, Kolbe M, Baker D, Becker S, Lange A. Atomic model of the type III secretion system needle. Nature. 2012; 486:276-279. [PubMed: 22699623]

(49). Loquet A, Lv G, Giller K, Becker S, Lange A. ${ }^{13} \mathrm{C}$ spin dilution for simplified and complete solid-state NMR resonance assignment of insoluble biological assemblies. J. Am. Chem. Soc. 2011; 133:4722-4725. [PubMed: 21401039]

(50). Das R, Andre I, Shen Y, Wu Y, Lemak A, Bansal S, Arrowsmith CH, Szyperski T, Baker D. Simultaneous prediction of protein folding and docking at high resolution. Proc. Natl. Acad. Sci. U.S.A. 2009; 106:18978-18983. [PubMed: 19864631]

(51). Kubori T, Sukhan A, Aizawa SI, Galan JE. Molecular characterization and assembly of the needle complex of the Salmonella typhimurium type III protein secretion system. Proc. Natl. Acad. Sci. U.S.A. 2000; 97:10225-10230. [PubMed: 10944190]

(52). Picking WL, Nishioka H, Hearn PD, Baxter MA, Harrington AT, Blocker A, Picking WD. IpaD of Shigella flexneri is independently required for regulation of Ipa protein secretion and efficient insertion of IpaB and IpaC into host membranes. Infect. Immun. 2005; 73:1432-1440. [PubMed: 15731041]

(53). Johnson S, Roversi P, Espina M, Olive A, Deane JE, Birket S, Field T, Picking WD, Blocker AJ, Galyov EE, Picking WL, Lea SM. Self-chaperoning of the type III secretion system needle tip proteins IpaD and BipD. J. Biol. Chem. 2007; 282:4035-4044. [PubMed: 17077085]

(54). Erskine PT, Knight MJ, Ruaux A, Mikolajek H, Wong Fat Sang N, Withers J, Gill R, Wood SP, Wood M, Fox GC, Cooper JB. High Resolution Structure of BipD: An Invasion Protein Associated with the Type III Secretion System of Burkholderia pseudomallei. J. Mol. Biol. 2006; 363:125-136. [PubMed: 16950399]

(55). Chatterjee S, Zhong D, Nordhues BA, Battaile KP, Lovell SW, De Guzman RN. The Crystal Structure of the Salmonella Type III Secretion System Tip Protein SipD in Complex with Deoxycholate and Chenodeoxycholate. Protein Sci. 2011; 20:75-86. [PubMed: 21031487]

(56). Lunelli M, Hurwitz R, Lambers J, Kolbe M. Crystal structure of PrgI-SipD: Insight into a secretion competent state of the type three secretion system needle tip and its interaction with host ligands. PLoS Pathog. 2011; 7:e1002163. [PubMed: 21829362]

(57). Zhang L, Wang Y, Olive AJ, Smith ND, Picking WD, De Guzman RN, Picking WL. Identification of the $\mathrm{MxiH}$ needle protein residues responsible for anchoring invasion plasmid antigen D to the type III secretion needle tip. J. Biol. Chem. 2007; 282:32144-32151. [PubMed: 17827155]

(58). Rathinavelan T, Tang C, De Guzman RN. Characterization of the Interaction between the Salmonella Type III Secretion System Tip Protein SipD and the Needle Protein PrgI by Paramagnetic Relaxation Enhancement. J. Biol. Chem. 2011; 286:4922-4930. [PubMed: 21138848]

(59). Espina M, Ausar SF, Middaugh CR, Picking WD, Picking WL. Spectroscopic and calorimetric analyses of invasion plasmid antigen D (IpaD) from Shigella flexneri reveal the presence of two structural domains. Biochemistry. 2006; 45:9219-9227. [PubMed: 16866368]

(60). Derewenda U, Mateja A, Devedjiev Y, Routzahn KM, Evdokimov AG, Derewenda ZS, Waugh DS. The structure of Yersinia pestis $\mathrm{V}$-antigen, an essential virulence factor and mediator of immunity against plague. Structure. 2004; 12:301-306. [PubMed: 14962390]

(61). Lee PC, Stopford CM, Svenson AG, Rietsch A. Control of effector export by the Pseudomonas aeruginosa type III secretion proteins PcrG and PcrV. Mol. Microbiol. 2010; 75:924-941. [PubMed: 20487288]

(62). Hamad MA, Nilles ML. Roles of YopN, LcrG and LcrV in controlling Yops secretion by Yersinia pestis. Adv. Exp. Med. Biol. 2007; 603:225-234. [PubMed: 17966419]

(63). Fields KA, Nilles ML, Cowan C, Straley SC. Virulence role of V antigen of Yersinia pestis at the bacterial surface. Infect. Immun. 1999; 67:5395-5408. [PubMed: 10496922] 
(64). Matson JS, Nilles ML. LcrG-LcrV interaction is required for control of Yops secretion in Yersinia pestis. J. Bacteriol. 2001; 183:5082-5091. [PubMed: 11489861]

(65). Lawton DG, Longstaff C, Wallace BA, Hill J, Leary SE, Titball RW, Brown KA. Interactions of the type III secretion pathway proteins LcrV and LcrG from Yersinia pestis are mediated by coiled-coil domains. J. Biol. Chem. 2002; 277:38714-38722. [PubMed: 12107165]

(66). Matson JS, Nilles ML. Interaction of the Yersinia pestis type III regulatory proteins LcrG and LcrV occurs at a hydrophobic interface. BMC Microbiol. 2002; 2:16. [PubMed: 12102728]

(67). Hamad MA, Nilles ML. Structure-function analysis of the C-terminal domain of LcrV from Yersinia pestis. J. Bacteriol. 2007; 189:6734-6739. [PubMed: 17644582]

(68). Mueller CA, Broz P, Muller SA, Ringler P, Erne-Brand F, Sorg I, Kuhn M, Engel A, Cornelis GR. The V-antigen of Yersinia forms a distinct structure at the tip of injectisome needles. Science. 2005; 310:674-676. [PubMed: 16254184]

(69). Espina M, Olive AJ, Kenjale R, Moore DS, Ausar SF, Kaminski RW, Oaks EV, Middaugh CR, Picking WD, Picking WL. IpaD localizes to the tip of the type III secretion system needle of Shigella flexneri. Infect. Immun. 2006; 74:4391-4400. [PubMed: 16861624]

(70). Epler CR, Dickenson NE, Bullitt E, Picking WL. Ultrastructural Analysis of IpaD at the Tip of the Nascent MxiH Type III Secretion Apparatus of Shigella flexneri. J. Mol. Biol. 2012; 420:29_ 39. [PubMed: 22480614]

(71). Broz P, Mueller CA, Muller SA, Philippsen A, Sorg I, Engel A, Cornelis GR. Function and molecular architecture of the Yersinia injectisome tip complex. Mol. Microbiol. 2007; 65:13111320. [PubMed: 17697254]

(72). Dickenson NE, Zhang L, Epler CR, Adam PR, Picking WL, Picking WD. Conformational Changes in IpaD from Shigella flexneri upon Binding Bile Salts Provide Insight into the Second Step of Type III Secretion. Biochemistry. 2011; 50:172-180. [PubMed: 21126091]

(73). Barta ML, Guragain M, Adam P, Dickenson NE, Patil M, Geisbrecht BV, Picking WL, Picking WD. Identification of the bile salt binding site on IpaD from Shigella flexneri and the influence of ligand binding on IpaD structure. Proteins. 2012; 80:935-945. [PubMed: 22423359]

(74). Pope LM, Reed KE, Payne SM. Increased protein secretion and adherence to HeLa cells by Shigella spp. following growth in the presence of bile salts. Infect. Immun. 1995; 63:3642-3648. [PubMed: 7642302]

(75). Olive AJ, Kenjale R, Espina M, Moore DS, Picking WL, Picking WD. Bile salts stimulate recruitment of IpaB to the Shigella flexneri surface, where it colocalizes with IpaD at the tip of the type III secretion needle. Infect. Immun. 2007; 75:2626-2629. [PubMed: 17296762]

(76). Stensrud KF, Adam PR, La Mar CD, Olive AJ, Lushington GH, Sudharsan R, Shelton NL, Givens RS, Picking WL, Picking WD. Deoxycholate interacts with IpaD of Shigella flexneri in inducing the recruitment of IpaB to the type III secretion apparatus needle tip. J. Biol. Chem. 2008; 283:18646-18654. [PubMed: 18450744]

(77). Prouty AM, Brodsky IE, Manos J, Belas R, Falkow S, Gunn JS. Transcriptional regulation of Salmonella enterica serovar Typhimurium genes by bile. FEMS Immunol. Med. Microbiol. 2004; 41:177-185. [PubMed: 15145463]

(78). Prouty AM, Gunn JS. Salmonella enterica serovar typhimurium invasion is repressed in the presence of bile. Infect. Immun. 2000; 68:6763-6769. [PubMed: 11083793]

(79). Wang Y, Nordhues BA, Zhong D, De Guzman RN. NMR Characterization of the Interaction of the Salmonella Type III Secretion System Protein SipD and Bile Salts. Biochemistry. 2010; 49:4220-4226. [PubMed: 20397637]

(80). Miki T, Okada N, Shimada Y, Danbara H. Characterization of Salmonella pathogenicity island 1 type III secretion-dependent hemolytic activity in Salmonella enterica serovar Typhimurium. Microb. Pathog. 2004; 37:65-72. [PubMed: 15312846]

(81). Faudry E, Vernier G, Neumann E, Forge V, Attree I. Synergistic pore formation by type III toxin translocators of Pseudomonas aeruginosa. Biochemistry. 2006; 45:8117-8123. [PubMed: 16800636]

(82). Neyt C, Cornelis GR. Insertion of a Yop translocation pore into the macrophage plasma membrane by Yersinia enterocolitica: Requirement for translocators YopB and YopD, but not LcrG. Mol. Microbiol. 1999; 33:971-981. [PubMed: 10476031] 
(83). Kaniga K, Tucker S, Trollinger D, Galan JE. Homologs of the Shigella IpaB and IpaC invasins are required for Salmonella typhimurium entry into cultured epithelial cells. J. Bacteriol. 1995; 177:3965-3971. [PubMed: 7608068]

(84). Menard R, Sansonetti PJ, Parsot C. Nonpolar mutagenesis of the ipa genes defines IpaB, IpaC, and IpaD as effectors of Shigella flexneri entry into epithelial cells. J. Bacteriol. 1993; 175:58995906. [PubMed: 8376337]

(85). Frithz-Lindsten E, Holmstrom A, Jacobsson L, Soltani M, Olsson J, Rosqvist R, Forsberg A. Functional conservation of the effector protein translocators PopB/YopB and PopD/YopD of Pseudomonas aeruginosa and Yersinia pseudotuberculosis. Mol. Microbiol. 1998; 29:1155-1165. [PubMed: 9767584]

(86). Menard R, Prevost MC, Gounon P, Sansonetti P, Dehio C. The secreted Ipa complex of Shigella flexneri promotes entry into mammalian cells. Proc. Natl. Acad. Sci. U.S.A. 1996; 93:12541258. [PubMed: 8577750]

(87). Tucker SC, Galan JE. Complex function for SicA, a Salmonella enterica serovar typhimurium type III secretion-associated chaperone. J. Bacteriol. 2000; 182:2262-2268. [PubMed: 10735870]

(88). Page AL, Ohayon H, Sansonetti PJ, Parsot C. The secreted IpaB and IpaC invasins and their cytoplasmic chaperone IpgC are required for intercellular dissemination of Shigella flexneri. Cell. Microbiol. 1999; 1:183-193. [PubMed: 11207551]

(89). Neyt C, Cornelis GR. Role of SycD, the chaperone of the Yersinia Yop translocators YopB and YopD. Mol. Microbiol. 1999; 31:143-156. [PubMed: 9987117]

(90). Job V, Mattei PJ, Lemaire D, Attree I, Dessen A. Structural basis of chaperone recognition of type III secretion system minor translocator proteins. J. Biol. Chem. 2010; 285:23224-23232. [PubMed: 20385547]

(91). Hume PJ, McGhie EJ, Hayward RD, Koronakis V. The purified Shigella IpaB and Salmonella SipB translocators share biochemical properties and membrane topology. Mol. Microbiol. 2003; 49:425-439. [PubMed: 12828640]

(92). Broms JE, Forslund AL, Forsberg A, Francis MS. Dissection of homologous translocon operons reveals a distinct role for YopD in type III secretion by Yersinia pseudotuberculosis. Microbiology. 2003; 149:2615-2626. [PubMed: 12949185]

(93). Ryndak MB, Chung H, London E, Bliska JB. Role of predicted transmembrane domains for type III translocation, pore formation, and signaling by the Yersinia pseudotuberculosis YopB protein. Infect. Immun. 2005; 73:2433-2443. [PubMed: 15784589]

(94). Shen DK, Saurya S, Wagner C, Nishioka H, Blocker AJ. Domains of the Shigella flexneri type III secretion system IpaB protein involved in secretion regulation. Infect. Immun. 2010; 78:4999-5010. [PubMed: 20937761]

(95). Roehrich AD, Martinez-Argudo I, Johnson S, Blocker AJ, Veenendaal AK. The extreme C terminus of Shigella flexneri IpaB is required for regulation of type III secretion, needle tip composition, and binding. Infect. Immun. 2010; 78:1682-1691. [PubMed: 20086081]

(96). Barta ML, Dickenson NE, Patil M, Keightley A, Wyckoff GJ, Picking WD, Picking WL, Geisbrecht BV. The structures of coiled-coil domains from type III secretion system translocators reveal homology to pore-forming toxins. J. Mol. Biol. 2012; 417:395-405. [PubMed: 22321794]

(97). Montagner C, Arquint C, Cornelis GR. Translocators YopB and YopD from Yersinia enterocolitica form a multimeric integral membrane complex in eukaryotic cell membranes. $\mathrm{J}$. Bacteriol. 2011; 193:6923-6928. [PubMed: 22001511]

(98). Goure J, Pastor A, Faudry E, Chabert J, Dessen A, Attree I. The V antigen of Pseudomonas aeruginosa is required for assembly of the functional PopB/PopD translocation pore in host cell membranes. Infect. Immun. 2004; 72:4741-4750. [PubMed: 15271936]

(99). Marquart ME, Picking WL, Picking WD. Soluble invasion plasmid antigen C (IpaC) from Shigella flexneri elicits epithelial cell responses related to pathogen invasion. Infect. Immun. 1996; 64:4182-4187. [PubMed: 8926086]

(100). Picking WL, Coye L, Osiecki JC, Barnoski SA, Schaper E, Picking WD. Identification of functional regions within invasion plasmid antigen C (IpaC) of Shigella flexneri. Mol. Microbiol. 2001; 39:100-111. [PubMed: 11123692] 
(101). Hayward RD, Koronakis V. Direct nucleation and bundling of actin by the SipC protein of invasive Salmonella. EMBO J. 1999; 18:4926-4934. [PubMed: 10487745]

(102). Amer AA, Ahlund MK, Broms JE, Forsberg A, Francis MS. Impact of the N-terminal secretor domain on YopD translocator function in Yersinia pseudotuberculosis type III secretion. J. Bacteriol. 2011; 193:6683-6700. [PubMed: 21965570]

(103). Tomalka AG, Stopford CM, Lee PC, Rietsch A. A translocator-specific export signal establishes the translocator-effector secretion hierarchy that is important for type III secretion system function. Mol. Microbiol. 2012; 86:1464-1481. [PubMed: 23121689]

(104). De Geyter C, Vogt B, Benjelloun-Touimi Z, Sansonetti PJ, Ruysschaert JM, Parsot C, Cabiaux V. Purification of IpaC, a protein involved in entry of Shigella flexneri into epithelial cells and characterization of its interaction with lipid membranes. FEBS Lett. 1997; 400:149-154. [PubMed: 9001387]

(105). Tran Van Nhieu G, Caron E, Hall A, Sansonetti PJ. IpaC induces actin polymerization and filopodia formation during Shigella entry into epithelial cells. EMBO J. 1999; 18:3249-3262. [PubMed: 10369666]

(106). Myeni SK, Zhou D. The C terminus of SipC binds and bundles F-actin to promote Salmonella invasion. J. Biol. Chem. 2010; 285:13357-13363. [PubMed: 20212042]

(107). Kueltzo LA, Osiecki J, Barker J, Picking WL, Ersoy B, Picking WD, Middaugh CR. Structurefunction analysis of invasion plasmid antigen C (IpaC) from Shigella flexneri. J. Biol. Chem. 2003; 278:2792-2798. [PubMed: 12427760]

(108). Terry CM, Picking WL, Birket SE, Flentie K, Hoffman BM, Barker JR, Picking WD. The Cterminus of IpaC is required for effector activities related to Shigella invasion of host cells. Microb. Pathog. 2008; 45:282-289. [PubMed: 18656530]

(109). Cornelis GR. The type III secretion injectisome. Nat. Rev. Microbiol. 2006; 4:811-825. [PubMed: 17041629]

(110). Menard R, Sansonetti P, Parsot C, Vasselon T. Extracellular association and cytoplasmic partitioning of the IpaB and IpaC invasins of S. flexneri. Cell. 1994; 79:515-525. [PubMed: 7954817]

(111). Kim BH, Kim HG, Kim JS, Jang JI, Park YK. Analysis of functional domains present in the Nterminus of the SipB protein. Microbiology. 2007; 153:2998-3008. [PubMed: 17768243]

(112). Lokareddy RK, Lunelli M, Eilers B, Wolter V, Kolbe M. Combination of two separate binding domains defines stoichiometry between type III secretion system chaperone IpgC and translocator protein IpaB. J. Biol. Chem. 2010; 285:39965-39975. [PubMed: 20937829]

(113). Schreiner M, Niemann HH. Crystal structure of the Yersinia enterocolitica type III secretion chaperone SycD in complex with a peptide of the minor translocator YopD. BMC Struct. Biol. 2012; 12:13. [PubMed: 22708907]

(114). Adam PR, Patil MK, Dickenson NE, Choudhari S, Barta M, Geisbrecht BV, Picking WL, Picking WD. Binding affects the tertiary and quaternary structures of the Shigella translocator protein IpaB and its chaperone IpgC. Biochemistry. 2012; 51:4062-4071. [PubMed: 22497344]

(115). Lunelli M, Lokareddy RK, Zychlinsky A, Kolbe M. IpaB-IpgC interaction defines binding motif for type III secretion translocator. Proc. Natl. Acad. Sci. U.S.A. 2009; 106:9661-9666. [PubMed: 19478065]

(116). Buttner CR, Sorg I, Cornelis GR, Heinz DW, Niemann HH. Structure of the Yersinia enterocolitica Type III Secretion Translocator Chaperone SycD. J. Mol. Biol. 2008; 375:9971012. [PubMed: 18054956]

(117). Hayward RD, Cain RJ, McGhie EJ, Phillips N, Garner MJ, Koronakis V. Cholesterol binding by the bacterial type III translocon is essential for virulence effector delivery into mammalian cells. Mol. Microbiol. 2005; 56:590-603. [PubMed: 15819617]

(118). Epler CR, Dickenson NE, Olive AJ, Picking WL, Picking WD. Liposomes recruit IpaC to the Shigella flexneri type III secretion apparatus needle as a final step in secretion induction. Infect. Immun. 2009; 77:2754-2761. [PubMed: 19433542]

(119). Collazo CM, Galan JE. The invasion-associated type III system of Salmonella typhimurium directs the translocation of Sip proteins into the host cell. Mol. Microbiol. 1997; 24:747-756. [PubMed: 9194702] 
(120). Thirumalai K, Kim KS, Zychlinsky A. IpaB, a Shigella flexneri invasin, colocalizes with interleukin-1 $\beta$-converting enzyme in the cytoplasm of macrophages. Infect. Immun. 1997; 65:787-793. [PubMed: 9009343]

(121). Obregon C, Dreher D, Kok M, Cochand L, Kiama GS, Nicod LP. Human alveolar macrophages infected by virulent bacteria expressing SipB are a major source of active interleukin-18. Infect. Immun. 2003; 71:4382-4388. [PubMed: 12874316] 


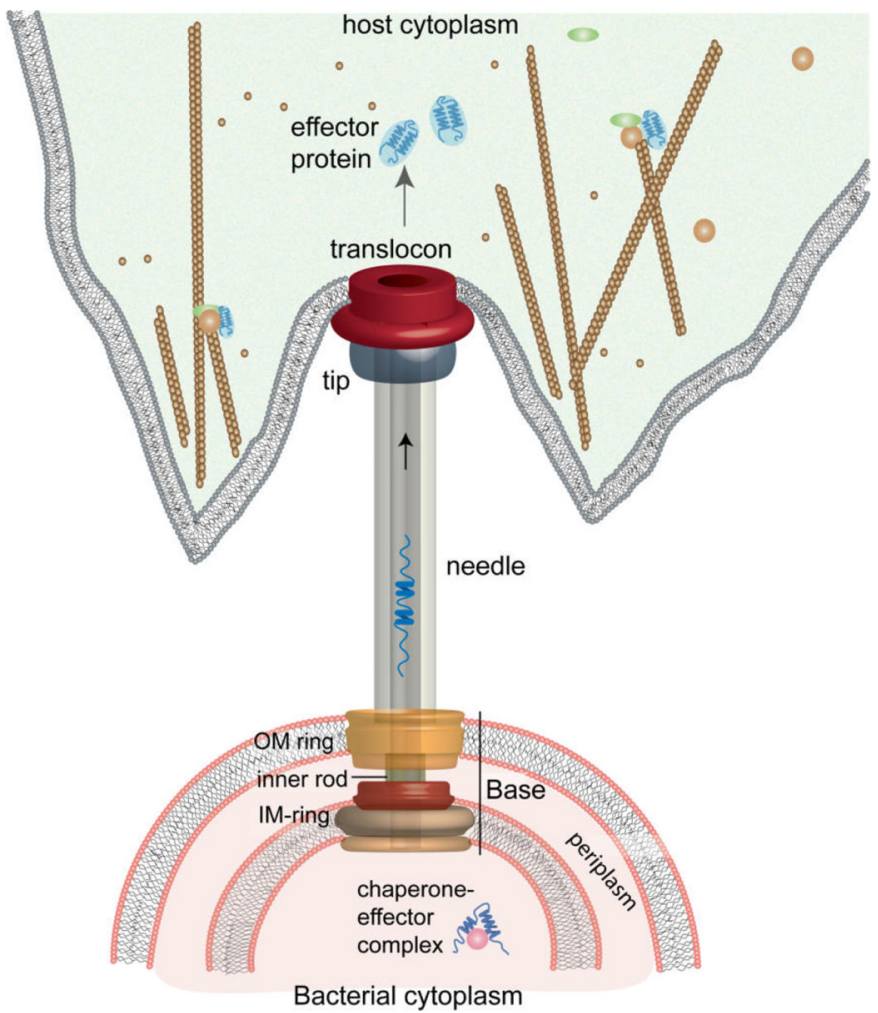

Figure 1.

Cartoon of the type III secretion system showing the needle apparatus in contact with the host cell. 

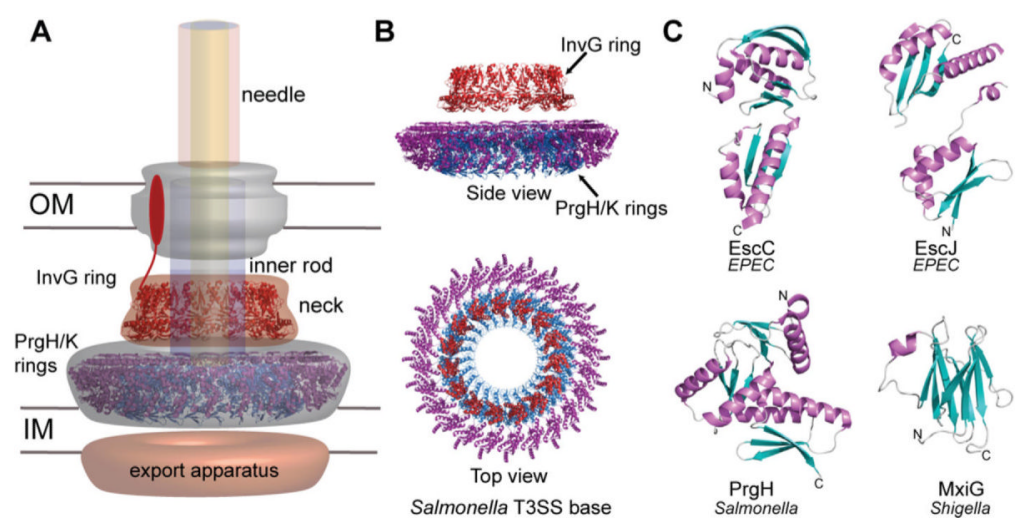

ESCJ

Salmonella T3SS base

Figure 2.

(A) Salmonella T3SS basal structure that spans the outer membrane (OM), the periplasm, and the inner membrane (IM) and is formed by (B) rings of InvG (red), PrgH (purple), and PrgK (blue).$^{20}$ (C) Structures of proteins that form the T3SS basal body: EPEC EscC, ${ }^{21}$ EPEC EscJ, ${ }^{18}$ Salmonella PrgH,${ }^{21}$ and Shigella MxiG. ${ }^{22}$ 
A

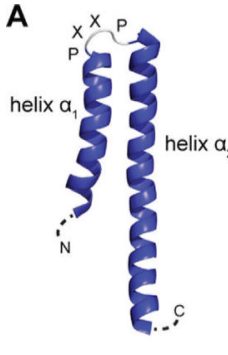

Prgl $\left.\right|^{\mathrm{C} \Delta 5}$
NMR
NMR

Prgl $^{*}$
NMR

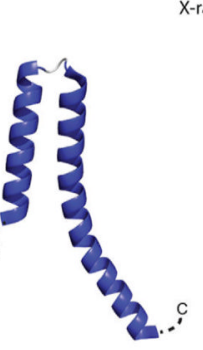

$\mathrm{MxiH}^{\mathrm{C} \Delta 5}$
Shigella

Shigella
$\mathrm{X}$-Ray

Polymerized MxiH
Shigella
Cryo-EM

Salmonella X-ray/NMR/ssNMR

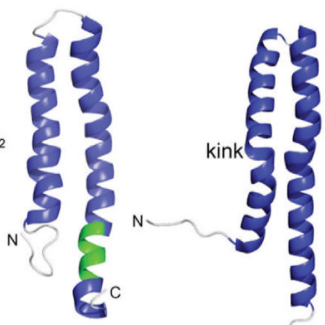

Figure 3.

(A) Structures of needle protomers Salmonella $\operatorname{PrgI} \mathrm{C}^{\Delta 5}(\mathrm{C} \Delta 5$, deletion of five C-terminal residues), ${ }^{42} \operatorname{PrgI} *$ (a functional V65A/V67A double mutant), ${ }^{43} \operatorname{PrgI}$ polymerized into needles, ${ }^{48}$ Shigella MxiH ${ }^{\mathrm{C} \Delta 5},{ }^{40} \mathrm{MxiH}$ polymerized into needles, ${ }^{47}$ and Burkholderia

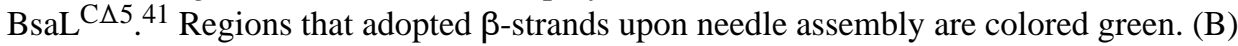
Atomic model of the Salmonella needle derived by solid-state NMR showing that the Nterminus of PrgI faces the exterior. ${ }^{48}$ 


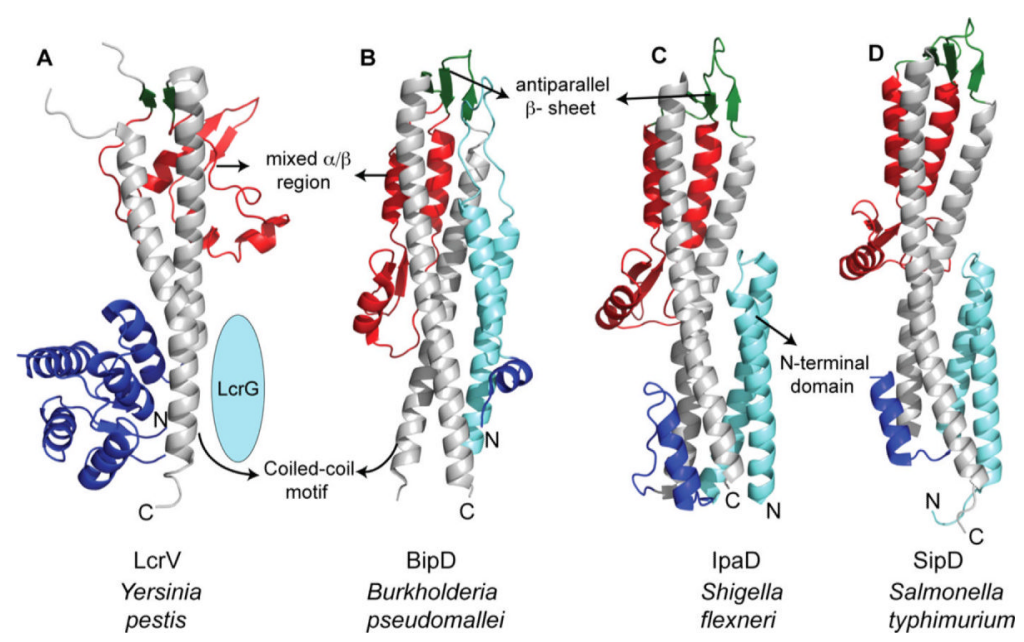

Figure 4.

Structure of tip proteins from (A) Y. pestis, ${ }^{60}$ (B) Burkholderia pseudomallei, ${ }^{54}$ (C) $S$. flexneri, ${ }^{53}$ and (D) S. typhimurium. ${ }^{55}$ 
A

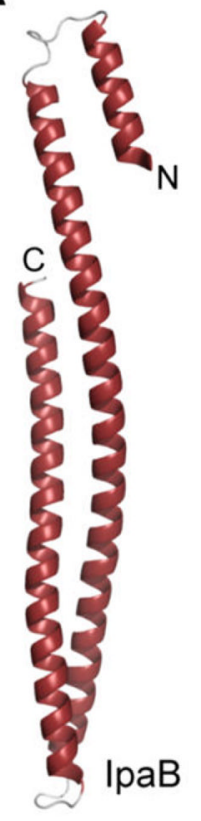

B

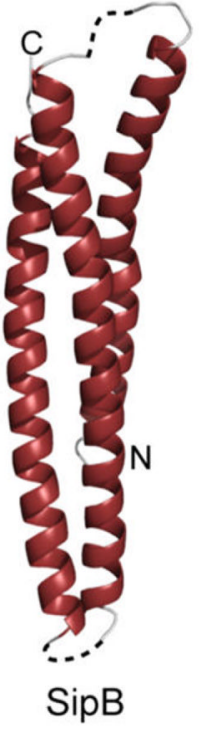

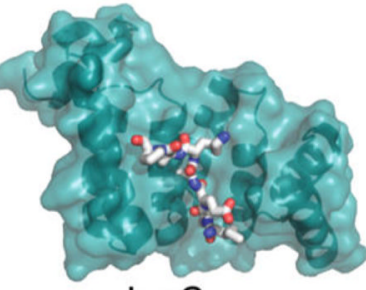

IpgC

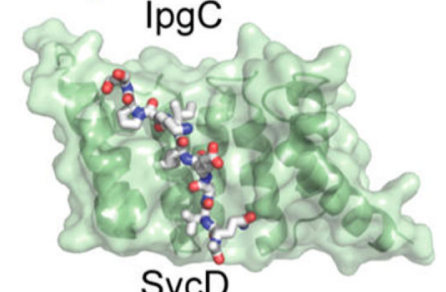

SycD

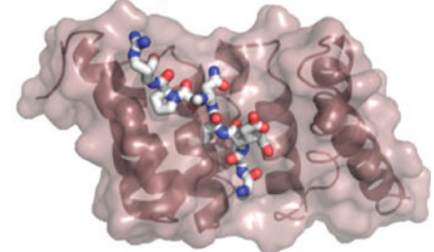

$\mathrm{PcrH}$

Figure 5.

(A) Structures of the N-terminal domains of the Shigella IpaB and Salmonella SipB translocon proteins. ${ }^{96}$ (B) Cocrystal structures of $\mathrm{IpgC},{ }^{115} \mathrm{SycD},{ }^{113}$ and $\mathrm{PcrH}^{90}$ chaperones bound to peptides derived from their cognate translocon proteins. 
Table 1

Structural Proteins of the T3SS Needle Apparatus

\begin{tabular}{llllll}
\hline role & Salmonella & Shigella & Yersinia & EPEC & Pseudomonas \\
\hline translocon & SipB & IpaB & YopB & EspB & PopB \\
translocon & SipC & IpaC & YopD & EspD & PopD \\
needle tip & SipD & IpaD & LcrV & EspA & PcrV \\
needle & PrgI & MxiH & YscF & EscF & PscF \\
OM ring & InvG & MxiD & YscC & EscC & PscC \\
inner rod & PrgJ & MxiI & YscI & EscI & PscI \\
IM ring & PrgK & MxiJ & YscJ & EscJ & PscJ \\
& PrgH & MxiG & YscD & EscD & PscD \\
export apparatus & SpaP & Spa24 & YscR & EscR & PscR \\
& SpaQ & Spa9 & YscS & EscS & PscS \\
& SpaR & Spa29 & YscT & EscT & PscT \\
& SpaS & Spa40 & YscU & EscU & PscU \\
ATPase & InvA & MxiA & YscV & EscV & PerD \\
\hline
\end{tabular}

